\title{
Asszonynévhasználat és asszonynév-változtatás a 20. század második felében"
}

1. A tanulmány témája és célkitüzései. Tanulmányom témáját a modern kori női névhasználat egy sajátos, kevéssé ismert területe, illetve jelensége képezi: a házasságkötéskor hivatalosan felvett asszonynevek későbbi megváltoztatásának esetei, ezek háttere, alakulása a 20. század második felében.

Az adott időszak megválasztását az magyarázza, hogy a hivatalos személynév-változtatások e típusával a 20. század közepétől, vagyis az asszonynévformák választékának első jogszabályi bővítésétől számolhatunk, legalábbis mint releváns névtani kutatási témával. Hasonló esetekre ezt megelőzően ritkán, alapvetően az elvált vagy megözvegyült nők esetében (s értelemszerüen a leánykori név visszavételére korlátozódóan) kerülhetett sor. Az asszonynévváltoztatások az itt vizsgált fél évszázad során azonban a házas nők névviselésének, névválasztékának, névválasztási szokásainak változásaival egyrészt jóval gyakoribb (a hivatalos családnév-változtatások, illetve az utónév-változtatások esetszámaival összemérhető) jelenséggé, másrészt és különösen pedig sokkal változatosabb, összetettebb kérdéskörré váltak.

E kérdéskör részleteit - akárcsak a hivatalos személynév-változtatások más típusai esetében (vö. SzÜTS 1970, FARKAS 2009: 14-16) - elsősorban az egykor a belügyminisztériumhoz benyújtott kérvények, vagyis az ezek ügyintézésével megbízott egykori minisztériumi osztály iratanyaga alapján tárhatjuk fel. A témakör vizsgálatában én is erre, illetve az ebből származó mintavételre támaszkodtam (ennek részleteiről 1. alább). A 21. század elejétől viszont, mely időszak a választható házassági névformák újabb (aktuálisan: legutóbbi) bövülését is eredményezte, a vizsgált folyamatok - a jogszabályi háttér átalakulása miatt (erről is 1. még később) - már kevéssé lennének követhetők. E szempont így nagyjából a feldolgozandó időszak végét is kijelöli számunkra.

Az alábbiakban mindenekelőtt a kérdéskör kutatását, a vonatkozó jogszabályi háttér változásait, a különböző asszonynévformák egyre bővülő palettáját igyekszem röviden és szükségszerüen bemutatni. A tanulmányom gerincét alkotó további fejezetekben az aszszonynevek megváltoztatásának indokrendszerét, az elhagyott és a felvett asszonynevek körében az egyes névformák megjelenési arányainak változásait, a jelenség időbeli alakulását és tendenciáit tárgyalom. Egymástól elkülönítve elemzem egyrészt a házas, másrészt az elvált (és a megözvegyült) nők asszonynév-változtatásainak eseteit. A névváltoztatók társadalmi hátterét kutatva az életkor és a lakóhely típusa (fóváros, város vagy falu) szerinti megoszlást vizsgálom; a további lehetséges szempontoktól, forrásaim ezekről csak esetlegesen tájékoztató jellege miatt, el kellett tekintenem. ${ }^{1}$ A házasságkötés idejének s ezáltal a hajdani asszonynévválasztás korabeli lehetőségeinek a figyelembevételéről pedig - mivel túlságosan megbonyolította volna a konkrét feldolgozást - gyakorlati okokból

${ }^{*}$ Készült az ELTE Bölcsészettudományi Karán a Tématerületi Kiválósági Program támogatásával.

${ }^{1}$ Ugyanakkor az asszonynév-választásokhoz hasonlóan itt is jól érzékelhető volt például, hogy különösen a nagyobb önállóságot vagy ismertséget jelentő, elsősorban értelmiségi pályán lévő nők számára bizonyult fontosnak a leánykori név nagyobb fokú kifejezése (vö. HaJdú 2000, RAÁTz 2003). 
mondtam le. A témakör meghatározó vonásainak bemutatását e szempontok mellőzése mindenesetre nem akadályozza.

A vizsgált korszak, az adott fél évszázad asszonynév-változtatási kérvényei és vizsgálatuk sajátos nézőpontot kínálnak a házassági névviseléssel kapcsolatos elvárásoknak, attitüdöknek, szempontoknak és ezek időbeli alakulásának a feltárására, illetve jobb megértésére. Eddig feltáratlan források alapján mutatnak rá azokra a folyamatokra, amelyek a házassági névviselés újabb trendjeinek és formáinak a megjelenéséhez vezettek, illetve mindennek a hátterében meghúzódnak. A jelenség a Magyarországon létező házassági névformák változatosságával együtt, illetve annak köszönhetően nemzetközi viszonylatban is egyedülállónak számít. Elemző bemutatása, úgy vélem, a témakör tágabb értelmű kutatása számára is tanulságosnak bizonyulhat.

2. A témakör kutatása és forrásai. A házassági névviselés időbeli változásainak tendenciáit, a kapcsolódó magyarországi jogszabályi háttér alakulását, az egyes névformák közti választást befolyásoló tényezőket számos tanulmány vizsgálta már a hazai szakirodalomban (a korábbi irodalom áttekintésére 1. FERCSIK 2008: 345-346, SzILÁGYI-KósA 2015: 147-148). E témakör az új évezred elejéig értelemszerủen az asszonynévhasználat elemzését jelentette, hiszen a férj házasságkötéshez kapcsolódó névváltoztatására csupán ekkoriban, konkrétan 2004-töl nyílt lehetőség a jogszabályváltozásoknak köszönhetően (bővebben 1. FARKAS 2003, tágabb kontextusához RAÁTZ 2004). A vonatkozó kutatások legnagyobb része - érthető módon - a hivatalosan felvett, illetve felvehető névformák körére vonatkozott, bár a mindennapok nyelvhasználatában mindig megtalálhatók voltak az anyakönyvekben bejegyezhető típusoktól eltérő változatok is.

E kutatások többsége azt vizsgálta, hogy milyen névformákat - és miért - választottak, illetve választottak volna vagy választanának a nők a házasságban. Az elvált nők névviselésének kérdésével foglalkozó - s így egyúttal a házasságkötéskor felvett név utólagos megváltoztatásának problematikáját is érintő - tanulmány inkább csak mutatóban született mellettük (FERCSIK 2003). Az egykor felvett asszonynév későbbi, hivatalos és tényleges megváltoztatásának témaköre azonban általánosságban feltáratlan maradt. Érthető módon: korántsem tömeges jelenségről volt szó, melynek több évtizedet érintő elsődleges forrásanyaga mindmáig a kutatók számára kevéssé hozzáférhető minisztériumi irattárban található, a hivatalosan viselt személynevek más típusait érintő kérvényanyaggal együtt. ${ }^{2}$

Magam egykori doktori kutatásom kapcsán, a 20. század utolsó éveiben, az elmúlt évszázad második felének hivatalos családnév-változtatásaival foglalkozva, e belügyminisztériumi irattári anyagban találkoztam a jelenséggel. Elkészült doktori értekezésem utolsó - alapvetö témájához képest járulékos jellegü - fejezetében fel is dolgoztam e kérdéskört (FARKAS 2001: 352-386), ám publikálására nem került sor. A jelenség vizsgálata során kapott eredmények - átdolgozott formában történő - közreadására így itt és most vállalkozom.

A jelen tanulmány alapjául is szolgáló kutatás a 20. század második felének névváltoztatásait az egyes évtizedekböl kiválasztott mintaévek forrásanyagából, évenként összesen 400-400 darab (az iratcsomók elejéről származó) engedélyezett család-, illetve asszonynévváltoztatási kérvény feldolgozásával igyekezett vizsgálni. Ez az egyes mintaévekből (1948, 1952, 1964, 1975, 1986, 1997) változó számú (0-176 eset/év) asszonynév-változtatási

${ }^{2}$ Ráadásul a párhuzamos, illetve közös ügyintézési gyakorlatnak megfelelően egymástól elkülönítetlen elhelyezéssel, ami szintén a lehetséges feldolgozást nehezítő tényező. 
kérvény anyagát eredményezte. (Az első, 1948-as mintaévet a jelen dolgozatból el is hagyom, tekintve, hogy mintavételemben az itt tárgyalt témakörbe tartozó adat nem szerepelt.) E forrásanyagot elsősorban kvantitatív, az indokrendszer vonatkozásában pedig kvalitatív szempontból elemzem. A kérvények szövegéből olykor konkrétan is hivatkozom, illetve szó szerint idézek majd (az eredeti, nem ritkán hibás írás- és fogalmazásmód megtartásával); ekkor az adott mintaév és az ügyintézés során kapott ügyiratszám megadásával utalok a pontos, az egykori belügyminisztériumi (BM) irattári anyagban található forrásra. (A vizsgált korpuszról bővebben l. FARKAs 2009: 15-16.)

\section{A házassági névviselés és névváltoztatás hivatalos keretei}

3.1. Az asszonynévhasználat szabályozásának változásai. A kialakult hagyomány, illetve a 19. század végén hivatalosan bevezetett állami anyakönyvezés értelmében házasságkötéskor megváltozik a nő neve. A korabeli névjog magától értetődőnek is tekintette, hogy „a leánynév egyedül való használata egyenesen megtévesztő volna az illető nő személyére vagy legalább is családi állására nézve" (SzEméLYi 1915: 119). A leánykori név formai megőrzésére később, a 20. század közepétől nyílt hivatalos lehetőség, a korábbi név szükségszerủ átértékelődésével, ti. úgy, hogy az a házasságkötés után immár asszonynévként, házassági névként funkcionált tovább. Az asszonynév a házasságkötés után a nő saját nevévé válik (vö. MEGYERI-PÁLFFI 2013: 165-172), átvéve korábbi, leánykori nevének szerepét a hivatalos használatban. A nő leánykori neve a későbbi házasságkötések után sem veszhetett el végleg a számára (később nyílhatott lehetőség a visszavételére), de a korábbi férj nevének (ti. -né képzős formában való) felvételére egy újabb házasságot követően már értelemszerüen nem maradt jogosult.

Az asszonynév különböző típusai a férj nevéből, illetve a feleség leánykori nevéből hozhatók létre, a 20. század derekát követő fél évszázad alatt folyamatosan és lényegesen bővülő változatossággal. Az új asszonynévformák bevezetését, illetve a köztük való választást elsősorban a célszerüség, az egyenjogúság gondolata és a hagyományok szempontjai, illetőleg a család névbeli összetartozásának és az egyéni önazonosság kifejezésének szándéka; kulturális, érzelmi, elvi és gyakorlatias megfontolások befolyásolhatták és határozhatták meg - hol egymást erősítő, hol éppen egymás ellenében ható tényezőkként. Az, hogy az egyes asszonynévformák mennyire felelhettek, illetve felelhetnek meg ezeknek a szempontoknak, a vonatkozó szakirodalomban rendszeresen visszatérő kérdés, illetve vizsgálati szempont. Mindenesetre általánosságban elmondható, hogy a névválasztás tendenciáinak alakulásmódjai a társadalmi-kulturális körülmények és gondolkodásmódok változásairól tesznek tanúbizonyságot, s ez utóbbiak a kapcsolódó jogszabályoknak, illetve azok értelmezésének és gyakorlati alkalmazásának alakulásában is meghatározóak voltak. Mindezekkel együtt változott, bővült a választható asszonynévformák kínálata, de változott idővel ugyanazon asszonynévformák társadalmi-kulturális „értéke” is a nevek használói számára (vö. legújabban BARANYiné KóCZY 2020).

A házastársi névviselés szabályozásának történetét nem célom részletesebben bemutatni (a jogi szakirodalomból 1. erre Petrik 1988, Szamel 1993, UgróczKy 1997, MegYeriPÁLFFI 2013: 139-146), a választék folyamatos bővülésének lépéseit azonban szükséges itt is számba venni röviden. Az új jogszabály elfogadásának/hatályba lépésének alább megadott kettős évszáma szerint egy Hunyadi János és Szilágyi Erzsébet nevü személy házasságkötése esetén a következő asszonynévformák váltak egymást követően elérhetővé: 
1894/1895-től: Hunyadi Jánosné;

1952/1953-tól: Hunyadi Jánosné Szilágyi Erzsébet és Szilágyi Erzsébet is;

1974/1974-töl: Hunyadiné Szilágyi Erzsébet és Hunyadi Erzsébet is;

2002/2004-től: Hunyadi-Szilágyi Erzsébet, illetve Szilágyi-Hunyadi Erzsébet is.

$\mathrm{Az}$ ezredelőn végbement, legutóbbi bővítés ezen túlmenően a férjek számára is megnyitotta a házassági névviselésnek - a nőkénél továbbra is korlátozottabb - irányait: a $H u$ nyadi János változatlan megtartása mellett a Szilágyi János, Hunyadi-Szilágyi János vagy Szilágyi-Hunyadi János névformák közüli választás lehetőségét.

A házassági névviselés területét ma az új Polgári Törvénykönyv (2013. évi V. törvény) szabályozza, mely azonban nem hozott érdemi újdonságot a kérdéskörben.

A legutóbbi érdemi, 2004-ben életbe lépett változtatás indokolttá tette a házassági név és születési név terminusok használatba vételét a szakirodalomban is (FARKAS 2003: 137-138). Az ezt megelöző - s itt általam is tárgyalt - korszakra és jelenségekre vonatkozóan ugyanakkor az asszonynév és a leánykori név kifejezések is alkalmasnak látszanak, legalábbis e tanulmánynak (az itt használttól eltérő jogi terminológiát nem szükségszerüen követö) szóhasználatában.

3.2. Az asszonynevek megváltoztatásának szabályozása. Mind az 1952-ben, mind az 1974-ben elfogadott törvény féléves átmeneti időszakot biztosított, amelyben az adott családi állapotban lévő, asszonynevet viselő (házas, elvált és özvegy) nők könnyített eljárás keretében, az életbe lépő új szabályozás újonnan megnyílt lehetőségei szerint változtathattak a névviselésükön. A határidő letelte után viszont csak a hivatalos család- és utónévváltoztatások procedúrájához hasonló módon, belügyminisztériumi eljárás keretében nyílt lehetőség a viselt asszonynévforma megváltoztatására. ${ }^{3}$ Az ezredelőn bekövetkezett, legutóbbi kínálatbővítés már határidő nélkül kívánt egyszerüsített, csupán anyakönyvi eljárásban megvalósuló lehetőséget biztosítani a korábban felvett asszonynevek viselőinek az általuk hivatalosan használt névforma megváltoztatására. Ez az a már korábban említett tényezö, mely egyúttal azt is jelenti, hogy az itt vizsgált folyamat innentől már nem követhető nyomon egyértelmüen az e tanulmányban érvényesített módokon a továbbiakban.

Magának az adott asszonynévformának a megválasztására több alkalommal nyílhat, illetve nyílhatott lehetősége egy nönek. Törvényszerüen a házasságkötéskor, illetve egy újabb házasság megtörténtekor (melyet követően a korábbi -né képzős asszonynév mindenesetre már nem lehetett használatos), valamint a házasság megszűnését követően (özveggyé válás, érvénytelenné nyilvánítás vagy válás esetén). Az aktuálisan viselt asszonynévforma megváltoztatására adott lehetőséget ugyanakkor az a hivatalos eljárás is, melynek folyamatait e tanulmány vizsgálja. Ez a családi állapot aktuális megváltozása nélkül, attól függetlenül tette lehetővé e névváltoztatást, ti. az adott időpontban anyakönyvezhető típusok közötti váltást az asszonynevet viselő nők számára. Több kutatásból tudjuk, hogy korántsem minden nő volt elégedett az általa aktuálisan viselt asszonynévformával. Viszont csak kis részük szánta el magát arra, hogy a felmerülő nehézségeket (ügyintézést, költségeket, egyéb iratok cseréjét stb.) vállalva, meglévő asszonynevét hivatalos névváltoztatási eljárással lecserélje egy másik névformára. E tanulmányban értelemszerúen ez utóbbi eseteket és motivációikat vizsgálhatom.

\footnotetext{
${ }^{3}$ Így például 1975-ben, mely mintaévként szerepelt anyagomban, az általam vizsgált asszonynévváltoztatási kérvények benyújtóinak nagy része e határidőből kicsúszva kezdeményezte névviselésének megváltoztatását ennek az eljárásnak a révén.
} 
Az aktuálisan viselt asszonynévformát megváltoztató eljárásnak, a hivatalos névváltoztatások e típusának a jogi szaknyelvbeli megnevezése a (házastársi) névviselés engedélyezése volt (a témakörre jellemzö terminológiai bizonytalansággal; vö. UGRóCZKY 1997: 18). A jelenséget névtani szempontból viszont én inkább az asszonynévforma megváltoztatása, illetve asszonynév-változtatás kifejezéssel nevezem meg, mert véleményem szerint ez jelöli ki pontosabban és érthetőbben a helyét a (személy)nevek, illetve a névváltoztatások rendszerében.

3.3. Asszonynévhasználat - a jogszabályokon túl. Ezen a ponton érdemes egy kis kitérőt tenni annak a kérdéskörnek a kedvéért, amely a mindenkori hivatalosságban meglévő asszonynévformák kínálatán túlra mutat. Felmérések szerint ugyanis az elmúlt évtizedekben a nők az aktuálisan anyakönyvezhető névformákhoz képest többféle változatot is elképzelhetőnek tartottak, s az informális nyelvhasználatban is jellemzően szélesebb volt a paletta, még napjaink hivatalos választékához képest is (továbbvezetö irodalommal 1. FARKAS 2003: 134-135, 141-142; legújabban SzABÓ T. 2020: 138-139 is). Ezek a nem hivatalos névhasználatból ismert asszonynévformák azért is figyelemre méltók, mert a társadalmi igényt jelzik (vö. HAJDÚ 2000: 48-49), többük pedig konkrétan a hivatalos választékban később megjelent házassági névformákat előlegezi meg.

Az aktuálisan adott, hivatalosan meglévő választékon túlmutató igény az általam vizsgált forrásanyagban a családnév-változtatások kérvényanyagából is kimutatható volt. A majd csak az ezredelő hivatalos választékbővítésével bevezetett, Hunyadi-Szilágyi Erzsébet típusú nevek valójában már a 20. század utolsó évtizedében (anyagomban az 1997-es mintavételi évben) hivatalosan elöállítható névtípust jelentettek. Ilyet ugyanis házastársak is igényelhettek (föleg feleségek, de férjek is) összetartozásuk névbeli kifejezésére, s szándékukat családnév-változtatás révén, családnevüket a házastárs nevével kiegészítve, azt így kettős családnévvé alakítva valósíthatták meg. Azaz tulajdonképpen egy külföldi mintákból már ismert, de itthon még hivatalosan fel nem vehető házassági névformát tudtak ilyen módon, mintegy kerülő úton előállítani, amit a hivatalos, korabeli belügyminisztériumi elbírálás - az általa alkalmazott, hiánypótlást kérő formanyomtatvány bizonysága szerint - ráadásul bevett gyakorlatként ismert, azonosított és támogatott is. (Bővebben 1. FARKAS 2003: 135-136, vö. még FARKAS 2009: 91-96.) Családnév-változtatási eljárás keretében természetesen a férj szintén felvehette felesége családnevét már ekkoriban is. Ezek mint házasságkötéssel megszerezhető, azaz hivatalos házassági névformák az adott időszakban még nem álltak rendelkezésre. Nyilván nem véletlen ugyanakkor, hogy éppen az itt említett - s néhány évvel később be is vezetett - két házassági névforma Magyarországon nem létező voltát hangsúlyozta az a véletlenül szintén 1997-ben megjelent belügyminisztériumi kiadvány (UGRÓCZKY 1997: 27), mely az aktuális névjogi szabályozást igyekezett röviden és gyakorlatias módon (többek közt, nyilván: az aktuálisan felvetődő problémákra is reflektálva) összefoglalni.

Megjegyzem, családnév-változtatással egyébként az együttélő párok számára hasonló módon nyílhatott lehetőség egyes (legalábbis -né képző nélküli) házassági névtípusokkal megegyező névformák előállítására (mint a férfi családneve + a nő keresztneve típusnak, illetve a két családnév összekapcsolásának az esetében). Vizsgált korszakomban ezt eleinte kevéssé engedélyezték, a végén viszont már jellemzően lehetővé tették a gyakorlatban (FARKAS 2001: 358). A születési és a házassági név mellé az élettársi név típusát mindenesetre később, illetve azóta sem vezették be a magyarországi személynévhasználatba (1. bővebben MegYeri-PÁlfFi 2013: 172-182). 
A kérdés egyik oldala tehát az, hogy egy adott személynév jogi és hivatalos szempontból minek minősül, hogyan jön létre és miképpen használható. A másik oldalát viszont az jelenti, hogy a névhasználó és környezete számára mit fejez ki, minek látszik, minek érződik, azaz ilyen értelemben miképpen funkcionál az adott személynévforma. Mindez legalább annyira érdekes szocioonomasztikai kérdés, mint hogy a hivatalos és nem hivatalos névhasználat hogyan térhet el egymástól, s hogy milyen jelentősége van a mindenkori hivatalos névnek az adott névviselő számára. Ehhez a problémakörhöz kapcsolódik a hivatalos asszonynév-változtatások jelenségének a vizsgálata is.

4. Az asszonynév-változtatások folyamatának mennyiségi alakulása. Az asszonynévformák megváltoztatásainak számszerü alakulását nehéz lenne kellő pontossággal megbecsülni. Bár korábban tettem rá egyfajta kísérletet (FARKAS 2001: 363-365), ennek eredményét nem tekinthetjük teljesen megbízhatónak. A jelenség gyakoribbá válása azonban világosan kirajzolódó folyamatként azonosítható a vizsgált fél évszázad folyamán.

Mint már utaltam rá, a jelenség a házasságon kívül élő (özvegy vagy elvált) nők körében tünt fel először, az asszonynév teljes elhagyását jelentő, a leánykori név visszavételére irányuló kérelmezői szándékok megvalósításával. A házas nők esetében nyilvánvalóan csak akkor állt elő a lehetőség, amikor a többféle névviselési forma, illetve az ezek közti választás is: az 50-es évektől, a leánykori név lehetséges megtartásának, illetve a további névkombinációknak a hivatalos bevezetésével. Az asszonynévformák változtatásaira irányuló kérvények száma a vizsgált félszázad alatt mindenesetre folyamatosan nőtt (a 70-es és 80 -as évekre évi néhány százra becsülhetően), legnagyobb mértékét pedig (a korábbiak többszörösét, ezer fölötti esetszámot valószínüsítve csupán a házas nők körében is) a vizsgált fél évszázadnak a rendszerváltás utáni utolsó évtizedére érhette el. Az esetszámok gyarapodásának tendenciája ugyanazoknak a folyamatoknak a következménye, amelyek általában a női szerep értelmezésének és az asszonynévválasztás trendjeinek változásvizsgálata során is kimutathatók, s amelyek - egyéb tényezők mellett - a 21 . század elején a házassági névviselés lehetőségeinek további bővítését is eredményezték.

Külön is ki kell térnem az elvált (és kisebb számban: a megözvegyült) nők asszonynévváltoztatásainak számbeli alakulására. Ezek esetszámai is jól láthatóan gyarapodtak a korszak első felében, e tendencia alakulása azonban a vizsgált forrásanyagban egy idő után már nem követhető megfelelően. A jogi szabályozás ugyanis 1974-től időkorlátosan, 1983 után pedig immár anélkül egy, az anyakönyvvezetőnél való bejelentéssel megvalósítható lehetőséget adott a házasság megszünését követően a nőknek a névváltoztatásra (vö. MEgYeRI-PÁLFFI 2013: 163). A rendelkezésre álló belügyminiszteri kérvényanyag tehát az elvált és az özvegy nők esetében már csak az ezt követő, immár másodszori, tehát eleve jóval ritkábban megtörténő változtatások eseteit foglalhatja magába. A kérvényezés ezen módja nem apadt el a továbbiakban sem, azaz többszöri asszonynév-változtatások is elöfordultak. Ezeket viszont nem tekinthetjük a korábbi tendencia, illetve folyamat egyenes vonalú folytatásának, így attól részben elkülönítve vehetők majd csak figyelembe.

\section{Az asszonynévformák megváltoztatásainak indokai a házas nők körében}

5.1. Az indokok vizsgálatáról. Az asszonynév-változtatások indokait az alábbiakban nem az egyes asszonynévformákra vonatkoztatva, hanem a kérvényekben felmerülö indoktípusok szerint veszem sorra. Ezek megfogalmazódásában természetesen az egyes konkrét 
asszonynévformák lehetséges előnyei és hátrányai is meghatározó szerepet játszhatnak, melyek kérdéskörét az asszonynevek témájával foglalkozó szakirodalom (pl. RÉvÉsz 2000) már kimerítően tárgyalta, így ezek szempontjaira itt nem szándékozom külön kitérni. A választott asszonynévformák megváltoztatásának indokrendszerét a kérvényekben megfogalmazottak alapján fogom feldolgozni, bár természetesen a valós tényezőket ezek sem tárják fel feltétlenül teljes informativitással és megbízhatósággal. Olykor csak „,személyes, magán jellegü” okokra hivatkozó, „körülményeim úgy alakultak” vagy a ,jobban tetszik” típusú magyarázatokra találhatunk a benyújtott kérvényekben, máskor azonban világosan megfogalmazott szempontok vagy egész konkrét élethelyzetek tárulnak fel ezek anyagából a kutató számára.

Az asszonynév-változtatási szándékok aktualitásával kapcsolatban általánosságban azt lehet megállapítani, hogy a kérvényekben azonosítható, az alábbiakban számba vett indokok sokszor csak a házasságkötés után, esetleg új körülmények között merültek fel egyáltalán. Más esetekben a kérvényezők már a férjhez menetelkor szívesen választották volna a később külön eljárás keretében felvett asszonynévformát, ám akkor az hivatalosan még nem volt lehetséges (vagy legalábbis ők nem tudtak róla), avagy csak kevéssé volt elterjedt, s így e nők a társadalmi szokásrendnek, netán a család elvárásainak engedtek a házasságkötéskor asszonynevük megválasztásában. Más esetekből az derült ki, hogy a kérvényező a házasság megkötése előtt csupán nem gondolta át eléggé, milyen névformát lenne érdemes asszonynévnek választania.

A házas nők asszonyneveinek megváltoztatásában szerepet játszó indokok rendszerét az alábbiakban a családnév-változtatások vizsgálatára kialakított és alkalmazott tipológiát követve tárgyalom (vö. FARKAS 2009: 60-62), részben gyakorlati okokból, de egyúttal a két névváltoztatási típus összehasonlíthatóságát is elösegítő módon. Jól látható, hogy a családnévváltoztatások történetében meglévő indoktípusok az asszonynevek kategóriáját érintő névváltoztatások körében is mind megtalálhatók, bár rendszerint igen eltérő súllyal vannak jelen. Mindezeket ugyanakkor itt további, már kifejezetten az asszonynév-változtatásokra vonatkoztatható indoktípusokkal kell kiegészíteni. A házas nök körében megnyilvánuló indokok rendszere jelentős mértékben eltér, s jellemzően gazdagabb az elvált nők esetében megmutatkozókétól. Az utóbbiakra később külön, az elvált nők asszonynév-változtatásainak tárgyalása során térek ki kicsit részletesebben.

5.2. Az asszonynév-változtatások indokrendszere. Az asszonynév-változtatások indokai között meglehetőségen ritka volt a magyarosítási szándék. Érthető módon: az aszszonynévben - a férj vagy a feleség révén - megjelenő idegen családnevet eleve családnévváltoztatással lehetett a legkézenfekvőbb módon elhagyni, ráadásul a névmagyarosító törekvések egyébként is alapvetően visszaszorultak a vizsgált időszakra. Az ilyen típusú szándék szerepet kaphatott azonban az idegenes hangzású és írásmódú, nehézkes használatúnak számító családnevet tartalmazó asszonynév letételében, más névformára cserélésében. A külföldön kötött - s így külföldi típusú asszonynévhasználatot eredményező - házasságok esetében a magyar hagyományoknak megfelelö, -né képzős asszonynév felvételében azonosítható ez az indoktípus.

A családi okok, érthető módon, gyakran kaptak szerepet az asszonynévformák megváltoztatásában. A férj, illetve a feleség családnevének az asszonynévben való megjelenése - a név információtartalmának részeként - az adott családhoz (az előbbi esetben legalábbis a férjhez) való tartozást fejezhetett ki. Az alapformának tekintett családmodelltől azonban a valóság gyakran eltérhetett. Egy elvált nő kérvényéből idézve: „Úgy érzem, az lesz 
a legjobb, ha egyik gyermek apja nevét sem viselem, hanem a leánykori nevemet és nem lesz a későbbiek során ebből egyik gyermek részéről sem probléma" (99/1975. BM). A férj nevének (föleg egyértelmű módon, azaz -né képzős formában való) felvételére indíthatott a félreértések elkerülésének szándéka; ez különösen a közös gyerekekre való tekintettel, $\mathrm{s}$ akár egyenesen a családi béke helyreállításának érdekében válhatott fontossá. A férj nevének elhagyását még többféle, az itt tárgyalt további típusokba tartozó szándék motiválhatta, legjellemzőbben azonban a férjjel való kapcsolat megszakításának igénye (külön élö, bár válni nem akaró házastársak esetében, már a válás kimondása előtt, de föleg azt követően). A leánykori családi név visszavételére (a férj neve mellé vagy helyett) a régi családhoz való, hangsúlyos kötődés kifejezéseként is sor kerülhetett; érzelmi alapon vagy akár a „bevezetett üzleti kapcsolatok” fenntartásának érdekében.

A névazonosság kiküszöbölésének szándéka elsősorban a hagyományos, a férj teljes nevét -né képzős formában viselő asszonyok névváltoztatási kérvényeiben jelent meg. „Például orvosnál kiszólnak, hogy Kissné egyszerre 56 mozdulnak” - utal a jellemző problémára az egyik kérelmező (360/1997. BM). A tradicionális asszonynevek azonosító szerepében könnyen elöállhattak e zavarok, ha a férj (legalábbis az adott közösségben) gyakran előforduló családnevet, s föleg ha egyúttal gyakori keresztnevet viselt. De ezt eredményezhette a valós kapcsolaton alapuló névazonosság a férfiági névöröklési tendenciák révén, különösen a szülőkkel közös lakcímen és közös háztartásban. Az ilyesféle egybeesés a mindennapokban (például a munkahelyen, postai küldemények átvételének esetében otthon) érthető módon okozhatott nehézségeket. A névazonosság egy-egy munkahelyen számozással történő, joggal sérelmesnek érezhető megkülönböztetéshez is vezethetett a nök esetében. A családon belüli egyezés esetén, anyós és meny nevének egybeesésekor elsősorban persze az utóbbiak változtattak. Az elvált asszonyok körében, névviselésük lehetőségeiből adódóan akár az is megtörténhetett, hogy több nő ugyanannak a férfinak a nevét viselte, ami még ezeknél is kellemetlenebb helyzeteket teremthetett, föleg egyazon közösségen belül. Az elvált feleség ilyenkor nem ritkán élt az asszonynév megváltoztatásának lehetőségével. Arra is akadt ugyanakkor példa, hogy az új feleség eleve azért vette fel csupán később a -né képzős asszonynévformát, mert nem akart a korábbi feleséggel egyező nevet viselni. Előfordult az is, hogy a kínosnak érzett helyzetet a korábbi férj családnév-változtatással tudta csak megszüntetni, mivel az elvált feleségnek joga volt korábbi asszonynevét megőrizni. Ilyen eset nyomán akár az is megtörténhetett, hogy egy elvált asszony azért kérte vissza leánykori nevét, mert magyarázata szerint: „férjem válásunk után nevet változtatott, így én egy nem létező családi nevet viselek" (404/1986. BM).

Az egyszerübben használható név felvételének igénye szintén gyakran indíthatott az aktuálisan viselt asszonynév megváltoztatására. Egyes asszonynévformák (így a férj család- és/ vagy teljes neve mellett a feleség teljes nevét tartalmazó asszonynevek) ugyanis igen hosszú neveket eredményezhettek. Nem véletlen, hogy a Hunyadi Jánosné Szilágyi Erzsébet típus mindig is ritka volt az asszonynevek körében. De míg a Hunyadiné Szilágyi Erzsébet forma egyébként ideális (avagy a leginkább „kompromisszumos”) választásnak tünhetett, s ezért idővel a legnépszerübb asszonynévformává is vált, adott esetekben ugyancsak igen hosszú nevet jelenthetett (különösen olyan nők számára, akiknek hivatalosan használt nevüket munkakörükből kifolyólag, például közjegyzőként, gyakran kellett leírniuk). A férj és a feleség családnevének bizonyos fokú hasonlósága ez utóbbi névtípus esetében néha további problémákat okozott; például egy Kovácsné Kulcsár típusú névkombináció esetében, mely könnyen névtévesztéshez (ti. Kulcsárné Kovács formához) is vezethetett (vö. 170/1997. BM). 
A nyelvi alapú zavaró konnotáció megszüntetése igen ritkán volt kifejezett célja az asszonynév megváltoztatásának. Egy előnytelen konnotációkat keltő családnév felvételét vagy megtartását ugyanis már a házasságkötéskor el lehetett kerülni, illetve a (leendö) férj családnév-változtatása eleve megelőzhette ezt a helyzetet (a teljes forrásanyag szerint a cigányos nevet viselö, házasság előtt álló férfiak családnév-változtatásaiban nem is ritkán, 1. FARKAS 2009: 47). Bizonyos helyzetek azonban később állhattak elö, például a fent említett példában az átlagosnál hosszabbnak számító asszonynév Kulcsárné K. formában feltünő rövidítése, mely a benne rövidítésként szereplö betü miatt akár „,egy kicsit kellemetlen és ízléstelen megjegyzésekre ad okot" a keresztnév előtt kimondva (170/1997. BM).

Egyéb névszépítő szándék jelenléte, azaz a divat, a névízlés sokféle tényező által befolyásolt hatása természetesen az asszonynévformák változtatásainak körében is érvényesült. A férj neve és a leánykori név, illetve ezek együttes hatása egyaránt szerepet kaphatott ebben. Viszonylag sok kérvény fogalmazta meg az ,így tetszik” szempontot az indoklásában, de az efféle tömör megállapítások mögött számos más kategóriába tartozó indok legalább ennyire (s netán még inkább) feltehető. Akadt ugyanakkor olyan kérvényező is, aki kimondottan ,a mai divatnak megfelelö” (konkrétan: modernebb, a müvészvilágban elönyösebb) asszonynévformát kívánt felvenni aktuálisan viselt asszonyneve helyett.

A nem hivatalos névhasználathoz igazodás igényének több kérvényben való megjelenése ugyancsak jól példázza azt, hogy a nők, illetve a környezetükben élők gyakran nem a hivatalos asszonynevet használták a mindennapok során. Ez jelenthette a hivatalosan egykor nem anyakönyvezett, de később elérhetővé tett névformákat is, elsősorban persze az 1975 előtti kínálatbővítésre vonatkozóan, s különösen a közszerepléssel járó pályákon levő nők esetében. A Hunyadi Erzsébet vagy a Szilágyi Erzsébet típus például a szóbeliségben, a mindennapi névhasználatban kétségkívül gyakoribb lehetett, mint azt pusztán a hivatalos névhasználat alapján feltételezhetnénk.

A korábban viselt név megváltozásából adódó gyakorlati nehézségek ugyancsak érthető módon késztethették arra a nőket, hogy a házasságkötéskor felvett asszonynevet egy másik lehetséges asszonynévformára cseréljék. Egyesek a felvett új nevet nem voltak képesek megszokni, s ezért kérték vissza korábbi nevüket. A leánykori nevet házasságkötéskor elhagyó asszonyok esetében - az asszonynevek kérdéskörének ismert problémájaként - a mások általi azonosíthatóság, sőt a megszólíthatóság is problematikussá válhatott. „Tapasztalatból tudom, hogy a L[...] Gáborné típusú névviselés egy elavult forma. Rólam nem mond el semmit, csak azt, hogy van egy férjem. Bemutatkozás után nem tudnak megszólítani, mert nem tudják a keresztnevemet" - amint a kérvények közt is megfogalmazódik. (586/1997. BM.) A tapasztalatok szerint a szóbeli kiegészítés sem lehetett feltétlenül elégséges: „Utónevemet nem tudja meg a másik fél, csak akkor, ha még külön ezt is hozzáteszem. Ez így már egy kicsit hosszú és volt úgy, hogy nem is rögzült a másik félben.” (569/1986. BM.) A leánykori név háttérbe szorulása különösen bizonyos életpályák, munkakörök esetén (így orvosok, jogászok, tudományos pályára lépő asszonyok esetében) bizonyulhatott problematikusnak. Az előbbiek számára a lánykori név és a doktori cím használata nem pusztán presztízskérdésnek, hanem munkájukban is elengedhetetlennek számíthatott, ha ezen a néven kapták meg diplomájukat, s ehhez kapcsolva használhatták doktori címüket. A múvészi pálya hasonlóképpen, de akár egy önálló vállalkozás elindítása is előnyösebbé tehette a leánykori név (ha akár csak a férj nevéhez is kapcsolt) használatát.

Nem választható el teljesen a fentebbi indoktípustól, illetve indoktípusoktól az egyéniség és az egyenjogúság kifejezésének az asszonynév-változtatási kérvényekben gyakran 
megfogalmazódó szándéka (leghangsúlyosabban persze a leghagyományosabbnak számító, Hunyadi Jánosné névformát viselő asszonyok esetében). Közismert mozgatórugója ez a házassági névviselés fejlődéstörténetének, melynek során azonban egyre több tér és lehetőség nyílt e szempontok kifejeződésére. Ahogyan azt egy, az éppen bevezetett, $\mathrm{Hu}$ nyadiné Szilágyi Erzsébet névformát felvenni kívánó kérvényező megfogalmazta: „Bár a női egyenjogúság elsősorban tartalmi kérdés, meggyőződésem szerint ezt a tartalmat a névviselésre vonatkozó új törvény adta lehetöségek közül az általam kért új forma fejezi ki a legjobban" (198/1975. BM). A tradicionális asszonynévforma megváltoztatása gyakran azonban egyúttal további gyakorlati szempontok (iparengedély kiváltása, egyéni vállalkozás elkezdése stb.) miatt vált fontossá. Amint egy kérvényező fogalmazott: „önálló keresettel rendelkezem, gazdaságilag önálló vagyok, munkakörömnél fogva inkább leánykori nevemet használom" (6788/1975. BM).

Az aktuálisan viselt asszonynévforma megváltoztatásának igényét külső, a névviselő szándékaitól független hatások is befolyásolhatták. Az új asszonynévforma felvételére sokszor nem az illető nő saját igényei szerint, hanem környezete befolyása alatt került sor. Elsősorban az újabban megjelent, kevésbé megszokott, a családi állapotot (egyértelmüen) nem jelölö névformákat - a Hunyadi Erzsébet és Szilágyi Erzsébet típusokat - hagyták el ilyen indíttatásból az asszonyok a vizsgált időszakban. Évtizedekkel ezelött könnyen - a korabeli szóhasználattal élve - leányanyának nézték őket nevük alapján, s így stigmatizált helyzetben érezhették magukat. Ahogyan egy, a Hunyadi Erzsébet típusról a tradicionálisabb asszonynévformára visszaváltoztató nő kérvénye írja: „13 éve vagyunk házasok. Ez idő közben 3 gyermekünk született. A »társadalmi konvekcióknak « [sic] sajnos be kell hogy hódoljak [...] Egyszer már viseltem férjem teljes nevét, az 1974-es új rendelet lehetőséget adott azonban az idő múlik, és sokszor látom az emberek értetlenségét nevem hallatán.” (574/1986. BM.) A névforma újszerüségéből adódó nehézségek és a korabeli társadalmi elöítéletek kényszerítő hatása mellett a közvetlen család - leginkább természetesen a férj és annak családja - ellenzése is erre indíthatta a nőt; például akkor, ha a férj rendszeresen ezt emlegette: ,az én nevemet a 8 éve elvált feleségem viseli, de az igazi nem” (154/1986. BM). Egy, a vizsgált időszak végén készült felmérés eredményei szerint (FéLIX 1999: 38-39) egyébként a férjhez menő nők környezetében a leánykori név megtartását jóval nagyobb arányban ellenezték, mint a Hunyadi Erzsébet típusú névformát, ami pedig azt jelzi, hogy - szemben a szakirodalomban is gyakran olvasható véleménnyel - valójában nem annyira a férjezettség egyértelmủ megjelölését hiányolhatták egyes asszonynevekből, hanem inkább a férjjel való kapcsolat bármiféle névbeli kifejeződését.

A nem magyar névhasználat szempontja azon asszonyok névváltoztatásában kapott szerepet, akik - s idővel egyre többen - rendszeres munkakapcsolatba kerültek külföldiekkel, esetleg tartós külföldi tartózkodás előtt álltak. Ez érthető módon a hagyományos, de más nyelvi viszonyok közt értelmezhetetlen, illetve zavarokat okozó -né képzős asszonynévformák elhagyását tehette célszerüvé esetükben.

\section{Az asszonynévformák megváltoztatása a házas nők körében}

6.1. A névtípusok érintettsége a névváltoztatásokban. Az asszonynévformák változtatási tendenciáinak időbeli alakulását az alábbiakban a hivatalos eljárásban elhagyott (régi) és az ugyanekkor felvett (új) asszonynévformák képviseleti arányainak változásai szerint mutatom be. Az így összegzett asszonynév-változtatások - itt az 1975-ös mintaévtöl - az ötféle 
asszonynévforma esetén négy további névforma valamelyikének kiválasztását, mindösszesen tehát húszféle asszonynév-változtatási típust tettek lehetővé. Ezek módszeres, egyenkénti számbavételére azonban természetesen nem fogok külön-külön kitérni.

A házas nők körében az asszonynév-változtatás, a fentebb már tárgyaltak szerint, csupán az 1952. évet követően vált lehetségessé. 1953-tól a hagyományosnak számító aszszonynévformán túl két további, majd 1974-től ismét két újabb asszonynévformát tett elérhetővé a szabályozás, melyek onnantól mind a felvenni kívánt, mind az elhagyni szándékozott asszonynevek közt megjelenhettek. Ezt a szempontot jelzem az alábbi táblázatokban is, melyek az általam vizsgált évekből származó mintavételben mutatják be az egyes asszonynévformák jelenlétét a régi és az új asszonynevek közt. A táblázatok azon rubrikáit ugyanis, amelyek eleve nem jöhettek szóba az adott névforma és az adott év esetében, kihúzással (-) jelöltem. Azon rubrikákban, amelyekben az egyébként lehetséges előfordulásra csupán nem volt adat a vizsgált mintában, 0,0-val jelöltem aktuális hiányukat.

1. táblázat: Házas nők névváltoztatásai az elhagyott asszonynévforma szempontjából (\%)

\begin{tabular}{|c|c|c|c|c|c|}
\hline Korábbi asszonynévformák & 1952 & 1964 & 1975 & 1986 & 1997 \\
\hline Hunyadi Jánosné & - & 50,0 & 73,3 & 62,2 & 43,9 \\
\hline Hunyadi Jánosné Szilágyi Erzsébet & - & - & 8,0 & 9,0 & 11,0 \\
\hline Hunyadiné Szilágyi Erzsébet & - & - & 4,0 & 11,5 & 28,7 \\
\hline Hunyadi Erzsébet & - & - & 1,3 & 4,5 & 7,9 \\
\hline Szilágyi Erzsébet & - & 50,0 & 13,3 & 12,8 & 8,5 \\
\hline
\end{tabular}

2. táblázat: Házas nők névváltoztatásai a felvett asszonynévforma szempontjából (\%)

\begin{tabular}{|l|r|r|r|r|r|}
\hline \multicolumn{1}{|c|}{ Új asszonynévformák } & $\mathbf{1 9 5 2}$ & $\mathbf{1 9 6 4}$ & $\mathbf{1 9 7 5}$ & \multicolumn{1}{|c|}{$\mathbf{1 9 8 6}$} & \multicolumn{1}{|c|}{1997} \\
\hline Hunyadi Jánosné & - & 16,7 & 13,3 & 8,9 & 6,7 \\
\hline Hunyadi Jánosné Szilágyi Erzsébet & - & 50,0 & 0,0 & 0,6 & 0,6 \\
\hline Hunyadiné Szilágyi Erzsébet & - & - & 50,7 & 59,9 & 26,1 \\
\hline Hunyadi Erzsébet & - & - & 13,3 & 9,6 & 24,2 \\
\hline Szilágyi Erzsébet & - & 33,3 & 22,7 & 21,0 & 42,4 \\
\hline
\end{tabular}

6.2. A tendenciák vizsgálata. Először a jelenség időbeli alakulása szerint tekintve át a vizsgált anyagot megállapítható, hogy a 60-as évek derekán, egy évtizeddel az asszonynévformák körét kibővítő jogszabályváltozás után még elég csekély volt az érdeklődés az asszonynév-változtatás lehetősége iránt. Habár korántsem reprezentatívnak számító mintavétel alapján, de jellemzőnek tűnik, hogy ekkor a leginkább hagyományos, de legszemélytelenebbnek tünő Hunyadi Jánosné típus, illetve a nő teljes saját nevét megőrző, de a férjre, férjezettségre egyáltalán nem utaló Szilágyi Erzsébet típus azonos arányban volt jelen az elhagyni kívánt asszonynevek közt. Az utóbbi, csupán egy évtizeddel korábban bevezetett típus jóval ritkább lehetett az előbbihez képest a korszak asszonynevei közt, tehát valójában erösen felülreprezentált módon tünik fel a kérvényanyagban. Ez egyébként nem feltétlenül meglepö: a társadalmilag megszokottól asszonynévként annyira eltért, hogy könnyen válhatott mindennapi kellemetlenségek és családi viták forrásává. A felvenni kívánt névformák közt az igen hosszú, de ekkoriban az egyetlen 
kompromisszumosnak számító lehetőséget képviselő változat bizonyult a legnépszerübbnek - különösen az eredetileg a leánykori nevüket megtartó, majd újabb asszonynévformát kereső nők számára - az adott, kis mintában.

A következő évtizedekben már nagyobb anyagon és immár öt lehetséges asszonynévforma esetében vizsgálhattam a tendenciák további alakulását. A kérvények szaporodását érthetővé teszi több tényező is. Az asszonynévválasztás lehetőségeinek kibővülése további névformákat kínálhatott a házasságban élő nőknek: olyan újabb, „kompromisszumos” változatokat is, amelyek férjük nevének és saját nevüknek a megtartására az eddig egyedül lehetséges, ám túlságosan hosszú asszonynév helyett egyúttal könnyebben használható nevet eredményezhetett. Ezeknek az új asszonynévformáknak a népszerübbé válását a házasságkötéskor választott asszonynevek vizsgálatával foglalkozó korabeli tanulmányok is világosan mutatják. Figyelemreméltó a tendencia, ahogy a házasság után megőrzött leánykori név elhagyása ritkábbá, felvétele viszont jóval gyakoribbá - az adott mintában az előbbinek a többszörösévé - vált. Nyilvánvalóan meghatározó szerepe volt ebben a női egyenjogúság eszméje térnyerésének s egyúttal e névforma ismertebbé és elfogadottabbá válásának, illetve további (alább még részletezendő) tényezőknek.

6.3. Az elhagyott asszonynevek állománya. A korszak tendenciáit az elhagyott nevek típusai szerint (1. táblázat) áttekintve megállapítható, hogy a legnagyobb arányt köztük mindvégig a Hunyadi Jánosné típus képviselte. Ugyanakkor e névforma képviseleti aránya lassan, de folyamatosan csökkent az anyagban, megfelelöen annak is, hogy már házasságkötésükkor eleve egyre kevesebben választották, a régebbi házasok jelentős része pedig, akik mindaddig nem cserélték le e névformát, kevésbé is kívánhattak már változtatni rajta. Mindemellett még a korszak végén is a legnagyobb csoportot alkották az elhagyni kívánt asszonynévformák közt, bár a névtípusnak a kérvényanyagon belüli aránya így is jócskán alulmúlta a korabeli népességben a házas nők körében meglévő képviseletét (pl. 1998-ban 78\%, vö. ERDÉSZNÉ 1999: 63). Az összes többi, elhagyni kívánt asszonynévforma a lakosságon belüli arányához képest felülreprezentált módon volt jelen a feldolgozott anyagban.

A táblázat alapján nyomon követhető arányok természetesen azt is jelzik, hogy az 1974 óta lehetségessé váló névformák is egyre nagyobb részt képviseltek az elhagyni kívánt asszonynevek között. A Hunyadi Jánosné Szilágyi Erzsébet típus nem csökkenni, inkább enyhén növekedni látszott; felvétele egykor jó kompromisszumnak tünhetett, de terjedelmes volta miatt könnyen célszerütlennek bizonyulhatott. ${ }^{4} \mathrm{Az}$ 1974-ben bevezetett két további asszonynévforma - a Hunyadiné Szilágyi Erzsébet és a Hunyadi Erzsébet típus - gyakoribbá vált nemcsak a házasságkötések alkalmával, de a más névformára cserélni kívánt nevek között is. A növekedés az előbbi esetében volt igazán figyelemre méltó (a korszak végére az elhagyandó nevek negyedét tette ki), bár az elhagyni kívánt nevek összességéből számítható részesedése így is határozottan alacsonyabb maradt, mint

\footnotetext{
${ }^{4} \mathrm{Az}$ adott asszonynévtípus adatai dolgozatomban ugyanakkor nem feltétlenül pontosak: a forrásanyagban nem mindig lehetett teljes egyértelmüséggel megállapítani, hogy a kérelmező hivatalosan viselte-e a férje teljes neve mellett a sajátját is, vagy a kérvényben csupán leánykori neveként tüntette fel mellette. (Vö. például a helyesírási szabályzat 10. kiadásának még az 1974. évi választékbővítés előtti, a lehetséges problémát jelző szövegével: „Az asszonynevekben a férj neve és a leánykori név közé nem teszünk vesszőt, s a szül. rövidítés kitétele is fölösleges: Takács Dezsőné Veres Katalin vagy Takácsné Veres Katalin stb.” AkH. ${ }^{10} 223$. pont.)
} 
ugyanezen időszakokban a házasságkötésekkor kimutatható (s kimagasló népszerüségét jelző) aránya. Az utolsó mintaévből származó anyagban a Hunyadi Erzsébet típust elhagyó nők egy része más országban szerzett asszonynevét kívánta „magyarosítani” egy ott nem engedélyezhető -né képzős asszonynévforma felvételével (legtöbbjük ekkoriban Romániából áttelepült magyar volt). A házasságkötés után megtartott leánykori nevüket elhagyni szándékozók aránya pedig egyre csökkent a korszak folyamán, nyilvánvalóan annak a jeleként, hogy e típus egyre megszokottabbá vált, azaz egyre inkább polgárjogot nyert a társadalom szemében is.

6.4. A felvett asszonynevek állománya. A felvenni kívánt asszonynevek között (2. táblázat) a hagyományos Hunyadi Jánosné típus sosem képviselt számottevőbb arányt, és folyamatosan csökkenő módon volt jelen. Ennek a feleség leánykori nevével kiegészített változata az asszonynévhasználatot új típusokkal gazdagító 1974-es rendelet után jóformán eltünik a feldolgozott mintából - párhuzamosan azzal, ahogyan a házasságkötéskor felvett nevek között is csekély arányban van jelen az adott évtizedek során. A Hunyadiné Szilágyi Erzsébet névforma eleinte egyértelmüen a legnépszerübbnek bizonyult: az asszonynév-változtatások bö felében volt jelen az első évtizedekben, míg a korszak végére a negyedére csökkent a képviselete - összefüggésben azzal, hogy akkorra az asszonynévformát változtatók egyre nagyobb része választotta immár a -né képző nélküli két további asszonynévforma valamelyikét. A Hunyadi Erzsébet típus a Hunyadi Jánosné típus arányához hasonló mértékben volt jelen bö egy évtizeden át - azzal ellentétben viszont magasabb arányban, mint a házasságkötéskor felvett nevek között -; a korszak végére viszont immár a névváltoztatási eljárás keretében felvett asszonynevek egynegyedét alkotta.

Jelentős arányváltozást mutatott a leánykori név felvételének (visszavételének) szándéka: a korábbi egyötödös aránya a korszak végére megkétszereződött. Ennek oka jelentős mértékben az lehetett, hogy a női egyenjogúság kiteljesedése és a rendszerváltozást követő gazdasági és társadalmi változások egyaránt előnyösebbé és elfogadhatóbbá tehették ennek a névformának a használatát, ami esetleg csak a házasságkötés után érlelte meg a névváltoztatási szándékot a névviselőben. E névformának a felvétele olykor a válásokat követő asszonynév-változtatásokkal is rokoníthatónak látszik: külön élő vagy kifejezetten válásra készülő asszonyok nemegyszer éltek ezzel a lehetőséggel, így is kifejezve a férjtől való függetlenségüket. Ezen kérvények számát növelték ugyanakkor, nem is csekély mértékben, azok az esetek, melyekben - a korábban már említett módon - technikailag ez a lépés nyitotta meg az utat az asszonynévformaként a korszak végén még nem elérhető, de egy családnév-változtatással megvalósítható Hunyadi-Szilágyi Erzsébet, illetve SzilágyiHunyadi Erzsébet személynévformák létrehozásához.

6.5. A folyamat társadalmi háttere. Az asszonynevüket a tárgyalt korszakban megváltoztató férjezett nők csoportját településtípus és életkor szerinti megoszlásuk szerint összesítve, immár a névváltoztatásban érintett névformákra való tekintet nélkül vizsgálom. Az alábbi táblázatokban mindkét szempontból a jelenség társadalmi továbbterjedésének hullámszerü voltát állapíthatjuk meg. E folyamatok nem függetlenek persze a házasságkötéskori névválasztások trendjeinek időbeli alakulásától, olyan értelemben sem, hogy az utóbbiak egyre inkább növelik a társadalom adott részlegein belül a „,modernebb", tehát a későbbi névváltoztatásokban általában kisebb eséllyel érintett asszonynevek képviseleti arányát. 
3. táblázat: Házas nők asszonynév-változtatásai a lakóhely szerint megoszlás szempontjából (\%)

\begin{tabular}{|c|c|c|c|c|c|}
\hline Lakhely típusa & 1952 & 1964 & 1975 & 1986 & 1997 \\
\hline Főváros & - & 83,3 & 52,0 & 42,3 & 26,8 \\
\hline Város & - & 16,7 & 38,7 & 41,7 & 53,7 \\
\hline Község & - & 0,0 & 9,3 & 16,0 & 19,5 \\
\hline
\end{tabular}

4. táblázat: Házas nők asszonynév-változtatásai az életkor szerint megoszlás szempontjából (\%)

\begin{tabular}{|c|c|c|c|c|c|}
\hline Korosztály & 1952 & 1964 & 1975 & 1986 & 1997 \\
\hline 30 év alatt & - & 80,0 & 62,2 & 43,9 & 40,3 \\
\hline $31-40$ év & - & 20,0 & 21,6 & 40,8 & 29,8 \\
\hline $41-50$ év & - & 0,0 & 10,8 & 8,9 & 22,4 \\
\hline $51-60$ év & - & 0,0 & 5,4 & 4,5 & 5,6 \\
\hline 61 év fölött & - & 0,0 & 0,0 & 1,9 & 1,9 \\
\hline
\end{tabular}

A településtípusok szerinti megoszlás (3. táblázat) alapján az asszonynév-változtatás - ahogyan sokáig a családnév-változtatás is - alapvetően urbánus jelenségnek számított. A fôvárosiak kezdeti túlnyomó aránya gyors tempóban apadt el, a 20. század végére már láthatólag jóval kisebb mértékben haladva meg a magyar lakosságon belüli tényleges képviseletüket. A fővároson kívüli városok részesedése ugyanakkor gyorsan növekedett, a nyolcvanas évek közepére elérte, majd le is hagyta - annak kétszeresére nőve - a fövárosét, kevéssel múlva így felül a teljes hazai lakosságon belüli arányukat. A falusi népesség részvétele ezzel szemben csak késve és meglehetősen lassan indult növekedésnek, a korszak végére is csupán az érintettek egyötödét jelentő módon. A falusi népesség alulreprezentáltságában nyilvánvalóan a falusi közösségek, életforma, munkalehetőségek eltérő jellemzőit kereshetjük; a hagyományok nagyobb és a hivatalos, írásbeli név kisebb szerepét.

Az életkor szerinti megoszlás (4. táblázat) szempontjából lényegében a 40, illetve 50 év alatti - azaz a fiatal és középkorú - asszonyokat találjuk a korszak névváltoztatói között. Az idősebbek láthatólag kevésbé akartak változtatni a gyakran már évtizedek óta megszokott, használt - vagy egy újabb házasságkötés révén már az újabb trendek szerint megválasztott - asszonynevükön. A legaktívabbak e téren a 30 év alattiak, a fiatal házasok voltak, akik életpályájuk kezdetén s a korszellemhez inkább igazodva szívesebben változtattak a házasságkötéskor - esetleg nem eléggé átgondoltan - választott asszonynéven. Részvételi arányuk lassú csökkenésének ellenére a 20 . század végén is még ez bizonyult a legjelentősebb csoportnak, mellettük azonban számottevően megnövekedett a harmincasok, majd pedig a negyvenesek generációjának jelenléte (az utóbbi kiemelkedő arányban a városokban). Ennek alapján feltételezhetjük, hogy azon nemzedékek zárkóztak fel idővel a fiatalabbak mellé, amelyeknek a tagjai többnyire akkor kötöttek házasságot, amikor az asszonynévformák szélesebb hivatalos választéka már létezett, de újabb típusai eleinte még kevésbé számítottak ismertnek, megszokottnak, s ez visszafoghatta a házasságkötéskor történő felvételüket. Az adatsorok itt látható alakulását ugyanakkor eleve nagyban befolyásolhatja, hogy a házasulandók átlagos életkora is egyre feljebb tolódott ugyanezen évtizedek során.

A településtípusok és az életkor szerinti megoszlás változásának képe jól kiegészíti egymást. Például az itt terjedelmi okokból mellőzött, részletesebb táblázatokból megállapítható 
lenne az is, hogy a harmincon felüli nemzedék minden településtípuson belül növekvő arányban jött fel, a falusi lakosság körében azonban ez is csak fáziskéséssel következett be. Mindez jól összecseng azon ismereteinkkel is, melyek a névadási divatok terjedésének általános - idő- és térbeli, illetve szociokulturális meghatározottságú csoportokon belüli módjára, jellegére vonatkoznak.

\section{Az asszonynévformák megváltoztatása a házasság után}

7.1. A jogszabályi háttér változásai. Az elvált (továbbá a megözvegyült) asszonyok névhasználatának kérdéskörét a házassági névviselés szabályaival együtt, illetőleg az azok változásait is motiváló társadalmi gondolkodásmód alakulásának figyelembevételével kellett rendezni, illetve alakítani a területre vonatkozó jogalkotás során. (Jogtörténeti áttekintését 1. MegYeri-PÁlffi 2013: 160-165.)

A 19. század végi szabályozás a válást követően alapesetnek tekintette a leánykori névhez való visszatérést. A házasság felbomlásában vétkesnek kimondott nő asszonynevét mindenképpen elvesztette, egyébként azonban kérhette a házasság alatt viselt név megtartását. 1952/1953-tól az elvált nő szintén tovább viselhette asszonynevét, ha a bíróság feljogosította rá, $\mathrm{s}$ ha nem vált arra (valamely súlyos büncselekmény elkövetésével) érdemtelenné. Tekintve, hogy ekkortól már többféle asszonynévforma létezett (a leánykori név megtartását is beleértve), azt is rögzítették, hogy bár az elvált nő a névviselését megváltoztathatja, a férje nevét (a további, -né képzős formák szerint) csak akkor használhatja a válást követően is, ha a házasság alatt is viselte. 1974-ben tovább változott a helyzet: a szabályozás ekkortól immár a névhasználat folytatólagosságát tekintette alapesetnek, amelytöl az elvált nő természetesen eltérhetett. Az asszonynevek ismét kibővült választékát is figyelembe véve egyértelmüen rögzítették, hogy bár a nő másféle asszonynévformát is választhat korábbi, házasságban viselt neve helyett, a férjezettséget egyértelműen jelölő, ti. -né képzős formát csak akkor választhat magának, ha hasonlót viselt a házasság fennállása alatt is. Mindezeken az elveken alapvetően az ezredelőn bekövetkezett újraszabályozás sem változtatott.

Az adott kérdésben érintett nők a válás kapcsán, illetve - a jogszabályok módosulásának köszönhetően, mint arról a korábbiakban volt szó - a korszak közepétől már az anyakönyvvezetőnél jelenthették be a névhasználatuk megváltoztatásával kapcsolatos szándékukat. Ennek megvalósítása ilyenkor tehát külön minisztériumi névváltoztatási eljárást nem igényelt. Ezen kívül, illetve túl azonban a belügyminisztériumi kérvényezés kínált megoldási lehetőséget céljuk megvalósításához.

A megözvegyült nők névviselése az elváltakéhoz több szempontból hasonló, ugyanakkor egyszerübb s így kisebb figyelmet kiérdemlő kérdéskört jelentett. Az özvegy a 19. század végén megtartotta, az itt vizsgált korszakban pedig ugyancsak megtarthatta férje nevét, amelyet a házasság során viselt, de aztán visszatérhetett korábbi nevéhez is, az aszszonynévformák választékának bővülésével pedig - úgy, mint az elvált nők - más változatra is lecserélhette azt.

Az említett szabályozások mellett, természetszerüleg, az elvált vagy megözvegyült nő újabb házassága esetén elveszítette a korábbi házasságkötéssel szerzett speciális jogait a névviselés terén. Ennek megfelelöen az általam vizsgált kérvényanyagban is rendre elutasították azokat a kérvényezőket, akik egy újabb házasság megszünte után korábbi -né képzős asszonynevüket szerették volna ilyen módon visszavenni. (Egy kivételt találtam 
anyagomban, melyet a kérelmező kiskorú gyermekeire való hivatkozással, de feltehetőleg inkább a volt házastársak belügyminisztériumi állására tekintettel engedélyeztek; 7737/1964. BM.) Megjegyzésre érdemes ugyanakkor, hogy ha ezek a nök viszont visszavették leánykori nevüket, kérvényezhették immár családnevük megváltoztatását a korábbi férj nevére, ami egy 1974-től már hivatalosan is létező asszonynévformával, a Hunyadi Erzsébet típussal egybeeső személynevet eredményezhetett. Ezt az eljárást pedig, mely a tényleges névhasználat szempontjából eredeti céljuk közelébe juttathatta e kérvényezőket, maga a minisztériumi ügyosztály is ajánlotta a számukra. (A problémakörhöz l. még UGRÓCZKY 1997: 26-27.)

Az eddigiekben elmondottak alapján megállapíthatjuk, hogy a területre vonatkozó jogi szabályozás során egyre inkább érvényre jutott az a szempont, miszerint az aszszonynév nem csupán a férjjel való kapcsolat kifejezője, hanem használata révén a nő saját nevévé is lesz, illetőleg akként funkcionál (vö. MegYeri-PÁlfFi 2013: 165-172). A házasságkötéssel szerzett név a nő önazonosságának részévé, névvel való azonosításának és másoktól való megkülönböztetésének az eszközévé válik, miközben a családi kapcsolatok körében a gyerekeivel való összetartozásának a kifejezője is. Ezek alapján a nőnek tehát jogos érdeke füződhet a házassággal szerzett név megtartásához akár a házasságot követően is, amit ezért az adott keretek közt támogatnak a jogszabályok (ide értve a Hunyadi Erzsébet típusú, illetve az ezredelőtől a házasságkötéskor összekapcsolt családi nevek újabb házasságba való átvihetőségének lehetőségét is). (Ennek a gyakorlatnak lehetett sajátos következménye azon eset is, melynek során a volt férj változtatta meg családnevét azért, hogy ne kelljen neki, illetve új házastársának a volt feleséggel közös, illetöleg megegyezö nevet viselnie.)

A továbbiakban az elvált nők asszonynév-változtatásainak jelenségét, illetve folyamatát igyekszem a házas nők körében lezajlott névváltoztatások fentebbi tárgyalásához hasonlóan bemutatni. Ezekkel együtt dolgozom fel a mintavétel során áttekintett azon kérvényeket is, melyek megözvegyült nők asszonynév-változtatási kéréseit tartalmazzák; ezekről, csekély számuk miatt, kevéssé lehetne külön, s föleg érdemben számot adni. Az alábbi elemzések hozzájárulhatnak a témakör vizsgálata során felmerülő olyan kérdések (vö. FerCsiK 2003: 621) megválaszolásához is, melyek az elvált nők névviselésének problematikáját segíthetnek mélyebben feltárni, illetve tágabb kontextusba helyezni.

7.2. A változtatások indokrendszere a házasságon túl. Az elvált nők asszonynévhasználatát érintő kérvények indokai a házas nőkéhez képest korlátozottabb körből kerültek ki. Ennek kapcsán elörebocsátható, hogy a változtatások tipikusan a férjezettséget kevésbé jelölö formák irányába mutattak. Ennek ellenkezőjét a hivatalos szabályozás - a korábban említett módon - bizonyos mértékig korlátozta is, de az alapvető tendencia egyébként is magától értetődőnek tekinthető.

A válást követő asszonynév-változtatások legnagyobb részében az érzelmi okok játszottak meghatározó szerepet (olykor egészen markáns megfogalmazásban, például: ,ilyen szadista egyénnek viselje a halál a nevét"; 225/1986. BM). A volt férj és a sikertelen házasság elfelejtése, valamint az asszonynév levetése - amit elsősorban a leánykori név visszavétele valósíthatott meg - természetszerüleg kapcsolódott össze a kérvényezők számára. Az egykori férj elítélendő életvitele még indokoltabbá tehette (több kérvényszöveg tanúsága szerint is) neve elhagyásának szándékát. 
Szintén fontos szerepet játszottak az elvált nők névváltoztatásaiban a régi családnévhez való kötődés, a régi családi kapcsolatok és a korábbi néven való ismertség szempontjai. A férjezettséget jelölö név használata ugyanakkor eleve félreértéseket okozhatott, föleg akkor, ha akár a volt feleség, akár a volt férj - még ha nem is házasság révén - új kapcsolatot talált magának.

A benyújtott kérvények az elvált nők asszonynév-változtatási szándékainak aktualitásaira is segíthetnek némi fényt deríteni. A korábbi férj nevének elhagyása olykor annak újranősülése kapcsán, máskor pedig az elvált nő új partnerének kérésére történt meg, azaz a későbbi, új házasságkötéskor amúgy bekövetkező névváltoztatást nem szándékozván kivárni. Az elvált nők jelentős része ugyanakkor nemcsak egyfajta társadalmi presztízs vagy más, gyakorlati okok miatt őrizte tovább egykori házassága révén szerzett nevét, hanem kiskorú gyermekeire való tekintettel is, míg ezek önállósodása után már könnyebben vetette le a volt férj nevét.

7.3. A tendenciák vizsgálata. Az alábbiakban az elhagyni, illetve felvenni kívánt névformák körét vizsgálom a házasság megszünését követően benyújtott asszonynévváltoztatási kérvényekben. A mintában elöforduló esetek túlnyomó többségét az elvált nők jelentik, mellettük kapott helyet néhány özvegyen maradt nő kérelme, illetve egy olyan eset, melyben egy nő elhunyt jegyese nevének felvételére kapott engedélyt (a világháborút követően lehetséges módon; vö. UGRÓCZKY 1997: 13). Az egyes évekből származó mintavétel így is csekély esetszámot képvisel, többnyire csak egy-másfél tucat kérvény adatait foglalja évenként magában (1952-ben pedig csupán egy elvált nő, egy özvegy és egy volt jegyes kérvényét). A felmérés reprezentativitása tehát alapvetően korlátozottnak tekintendő, de a kellő fenntartásokkal tájékoztatást tud adni az adott folyamatokról. Az egy-egy mintaév esetében nem elérhető asszonynévforma rubrikáját ezekben a táblázatokban is kihúzással (-) jelöltem.

Az alábbiakban az elhagyott asszonynevekre vonatkozó táblázatot ezúttal kétféle, a felvett névformákat feldolgozó táblázat követi. A már korábban említett 1974-es, illetve 1983-as (korszakunkat kettévágó) szabályozások ugyanis a minisztériumi kérvényezési eljárást megelőzően lehetővé tettek egy, az anyakönyvvezetőnél - először 60 napon belül, majd időkorlát nélkül - bejelenthető asszonynév-változtatást a házasság megszúnését követően. Innentől tehát már csak egy újabb, következő névváltoztatási szándék igényelte az olyan kérvény benyújtását, amely forrásanyagomban megjelenhetett. Így a két utolsó mintaévnek az elhagyni kívánt nevekre vonatkozó forrásanyagbeli adatai nem a házasságkötéskor felvett asszonynevet, hanem már maguk is megváltoztatott asszonynévformákat jelentenek.

Ezért a feldolgozott kérvényanyagban formálisan összetartozó, de mögöttes tartalmukat tekintve elkülönítendő adatsorokat normál és dőlt betüs szedéssel különítem el a korábbiakhoz egyébként hasonló (5. és 6.) táblázatokban. A házasság megszünését követő (ti. első) névváltoztatás új asszonynévformáiról korrektebb képet adó, korrigált (7.) táblázatot ezt követően közlöm. Megjegyzendő ugyanakkor, hogy ez utóbbi táblázatban, a két utolsó mintaév esetében az adott névforma felvételének idejét nem tudom pontosan megadni: az évszám itt csak annyit jelöl, hogy valamikor a vonatkozó jogszabályváltozások és az adott mintaév közti időszakban kerülhetett rá sor. Ez az elérhető asszonynévformák választéka szempontjából nem releváns különbség, az adott időszak asszonynév-változtatási tendenciáinak vonatkozásában azonban mégis módosítja az adott képet. 
5. táblázat: Elvált (és özvegy) nők névváltoztatásai az elhagyott asszonynévforma szempontjából (\%)

\begin{tabular}{|c|c|c|c|c|c|}
\hline Régi asszonynévformák & 1952 & 1964 & 1975 & 1986 & 1997 \\
\hline Hunyadi Jánosné & 66,7 & 90,0 & 96,8 & 27,8 & 9,1 \\
\hline Hunyadi Jánosné Szilágyi Erzsébet & - & 10,0 & 2,1 & 16,7 & 18,2 \\
\hline Hunyadiné Szilágyi Erzsébet & - & - & 0,0 & 44,4 & 63,7 \\
\hline Hunyadi Erzsébet & - & - & 0,0 & 5,6 & 0,0 \\
\hline Szilágyi Erzsébet & 33,3 & 0,0 & 1,1 & $\overline{5,6}$ & 9,1 \\
\hline
\end{tabular}

6. táblázat: Elvált (és özvegy) nők névváltoztatásai a felvett asszonynévforma szempontjából (\%)

\begin{tabular}{|l|r|r|r|r|r|}
\hline \multicolumn{1}{|c|}{ Új asszonynévformák } & \multicolumn{1}{|c|}{$\mathbf{1 9 5 2}$} & \multicolumn{1}{|c|}{$\mathbf{1 9 6 4}$} & \multicolumn{1}{|c|}{$\mathbf{1 9 7 5}$} & \multicolumn{1}{|c|}{$\mathbf{1 9 8 6}$} & \multicolumn{1}{c|}{1997} \\
\hline Hunyadi Jánosné & 33,3 & 0,0 & 0,0 & 5,6 & 0,0 \\
\hline Hunyadi Jánosné Szilágyi Erzsébet & - & 0,0 & 0,0 & 0,0 & 0,0 \\
\hline Hunyadiné Szilágyi Erzsébet & - & - & 6,3 & 0,0 & 9,1 \\
\hline Hunyadi Erzsébet & - & - & 0,0 & 0,0 & 0,0 \\
\hline Szilágyi Erzsébet & 66,7 & 100,0 & 93,7 & 94,4 & 90,9 \\
\hline
\end{tabular}

7. táblázat: Elvált (és özvegy) nők névváltoztatásai a felvett asszonynévforma szempontjából, a házasság megszünését követő első változtatás eredményét rögzítő adatokkal (\%)

\begin{tabular}{|l|r|r|r|r|r|}
\hline Új asszonynévformák (korrigált adatok) & \multicolumn{1}{|c|}{$\mathbf{1 9 5 2}$} & \multicolumn{1964}{|c|}{} & $\mathbf{1 9 7 5}$ & $\mathbf{1 9 8 6}$ (e.) & $\mathbf{1 9 9 7}(\mathbf{e .})$ \\
\hline Hunyadi Jánosné & 33,3 & 0,0 & 0,0 & 27,8 & 9,1 \\
\hline Hunyadi Jánosné Szilágyi Erzsébet & - & 0,0 & 0,0 & 16,7 & 18,2 \\
\hline Hunyadiné Szilágyi Erzsébet & - & - & 6,3 & 44,4 & 63,7 \\
\hline Hunyadi Erzsébet & - & - & 0,0 & 5,6 & 0,0 \\
\hline Szilágyi Erzsébet & 66,7 & 100,0 & 93,7 & 5,6 & 9,1 \\
\hline
\end{tabular}

7.4. Az elhagyott és a felvett nevek állománya. Az elhagyott és az újonnan felvett aszszonynévformák adatai együttesen és összességében azt mutatják, hogy - az adott körben korántsem meglepő módon - a kérvényezők túlnyomó többsége a férjezettséget nagyobb mértékben jelölő formákat kívánta elhagyni, felcserélni valamely nagyobb önállóságot kifejező változattal. A belügyminisztériumi eljárás során elhagyott asszonynevek palettáján (5. táblázat) a korábbi mintaévekben egyértelmüen a leghagyományosabb asszonynevek domináltak, már csak az asszonynévválasztás korábbi szükebb lehetőségeinek, de trendjeinek megfelelően is. Ez a kép az utolsó két mintaévben vált tarkábbá; ott, ahol ezek az adatok már egy korábban megtörtént asszonynév-változtatás eredményét tartalmazzák. Ezek esetében további megfontolások - az asszonynévformák teljes népességen belüli arányai, a megváltoztatott névformák megoszlása, illetve az általános tendenciák - alapján feltételezhetjük, hogy a korábban elhagyott asszonynevek a férjezettséget eröteljesebben jelölő névformák lehettek (legtöbbjük bizonnyal a Hunyadi Jánosné típus képviselője). Ezekre vonatkozó pontos adatokkal itt azonban nem rendelkezünk.

A belügyminisztériumi eljárással felvenni szándékozott nevek közt (a korrigálás nélküli, 6. táblázat szerint) csak kivételesen akadt a leánykori névtől eltérő névforma (jobbára 
csak a Hunyadiné Szilágyi Erzsébet típus aktuális képviselője). Ugyanakkor, mint említettem, az 1983-tól érvénybe lépő rendelet miatt ez önmagában még félrevezető képet mutat. A felvett, új asszonyneveket tartalmazó korrigált (7.) táblázat szerint az első változtatás során választott asszonynévformák között már inkább magasnak, mint alacsonynak tünik a legelső, hagyományos típus egyébként csökkenő aránya, ugyanakkor érthető a férj teljes nevének a feleség teljes nevével való kiegészítése - erősödő tendenciaként - mint első, legkönnyebb lépés az önállósodás kifejezésére. Ez a szempont magyarázza a Hunyadiné Szilágyi Erzsébet típus kiemelt, növekvő és túlsúlyba kerülö arányát itt, párhuzamban e névformának általánosságban, a korabeli házasságkötések során is egyre népszerübbé válásával. Ez az asszonynévforma - vagyis az egykori férj nevének, illetve a korábban használt asszonynévnek és a korábbi saját, az új állapothoz jobban illő leánykori névnek az együttese - valóban célszerü választást jelenthetett: nem szakított teljesen a rendszerint azt megelőző - a férj teljes nevét magába foglaló, viszont a feleség nevét akár egyáltalán nem tartalmazó - névformákkal; kevésbé volt hosszú, mint a mindkét korábbi házas fél teljes nevét tartalmazó, a teljes korabeli asszonynévállományhoz képest itt jellemző módon mégis jócskán felülreprezentált forma; azonosító szerepét pedig jól betölthette.

Érthetőnek látszik, ha a nők legnagyobb része - legalábbis eleinte - nem akart teljesen megszabadulni a házasság alatt viselt, -né képzős, sokak által ismert és bevettnek számító névtől, s e név megtartása (főleg kiskorú) gyermekei szempontjából is célszerünek bizonyulhatott. Emellett jelentkezett a törekvés a házasságkötés elött viselt, (teljes) leánykori név használatára. Ez magyarázza az említett, „kompromisszumos”-nak számító asszonynévformák (Hunyadi Jánosné Szilágyi Erzsébet, Hunyadiné Szilágyi Erzsébet) itteni kimagasló - a két utolsó mintaév során lényegesen megnövekedett - arányát. Képviseleti arányuk jóval nagyobb annál, mint amit a fentebbiekben, a férjezett nők által megváltoztatni kívánt asszonynevek között láthattunk; s még sokkal gyakoribbnak tünik, ha a teljes népességen belüli névviselés adataihoz viszonyítjuk azokat.

Egy potenciális másodszori asszonynév-változtatás eredményeit a két utolsó mintaév esetében vehetjük csak szemügyre; a belügyminisztériumi eljárás során felvett asszonyneveket tartalmazó, korrigálás nélküli (6.) táblázatban. Az újabb eljáráshoz folyamodó nők szándéka egyértelmü: szinte kivétel nélkül egykori házasságuk utolsó nyomait kívánták eltüntetni, leánykori nevük visszavételét tüzve ki egyértelmü célként.

7.5. A jelenség társadalmi háttere. A továbbiakban a házasság megszünését követően viselt asszonynév megváltoztatását kérelmező nők lakhely és életkor szerinti megoszlását vizsgálom. A két utolsó mintaév oszlopát itt is dőlt betüvel szedtem, jelezvén, hogy az ide sorolt kérelmek - a fentebb részletesebben elmondottak szerint - nem ugyanazt a névváltoztató csoportot jelentik, mint a korábbi mintaévek esetei, s ennek megfelelően a korábbi mintaévekből származó adatokkal együttesen kevéssé - de annál inkább külön - értékelendők.

8. táblázat: Elvált és özvegy nők névváltoztatásai a lakóhely szerinti megoszlás szempontjából (\%)

\begin{tabular}{|l|r|r|r|r|r|}
\hline \multicolumn{1}{|c|}{ Lakhely szerinti megoszlás } & \multicolumn{1}{c|}{$\mathbf{1 9 5 2}$} & \multicolumn{1}{|c|}{$\mathbf{1 9 6 4}$} & \multicolumn{1}{c|}{$\mathbf{1 9 7 5}$} & \multicolumn{1}{|c|}{$\mathbf{1 9 8 6}$} & \multicolumn{1}{c|}{1997} \\
\hline Főváros & 66,6 & 70,0 & 45,3 & 38,9 & 54,5 \\
\hline Város & 33,3 & 20,0 & 33,7 & 50,0 & 36,4 \\
\hline Község & 0,0 & 10,0 & 21,1 & 11,1 & 9,1 \\
\hline
\end{tabular}


9. táblázat: Elvált és özvegy nők névváltoztatásai az életkor szerinti megoszlás szempontjából (\%)

\begin{tabular}{|l|r|r|r|r|r|}
\hline \multicolumn{1}{|c|}{ Életkor szerinti megoszlás } & \multicolumn{1}{|c|}{$\mathbf{1 9 5 2}$} & \multicolumn{1}{|c|}{$\mathbf{1 9 6 4}$} & \multicolumn{1}{c|}{$\mathbf{1 9 7 5}$} & \multicolumn{1}{c|}{$\mathbf{1 9 8 6}$} & \multicolumn{1}{c|}{1997} \\
\hline 30 év alatt & 0,0 & 50,0 & 63,7 & 10,5 & 16,7 \\
\hline $31-40$ év & 0,0 & 16,7 & 15,9 & 36,8 & 8,3 \\
\hline $41-50$ év & 0,0 & 22,2 & 12,5 & 21,1 & 25,0 \\
\hline $51-60$ év & 100,0 & 11,1 & 4,5 & 15,8 & 41,7 \\
\hline 61 év fölött & 0,0 & 0,0 & 3,4 & 15,8 & 8,3 \\
\hline
\end{tabular}

Az itt tárgyalt folyamatokban érintett személyek szociológiai jellemzőivel kapcsolatban viszonylag kevés megállapítást tehetünk. Az jól látszik, hogy sokáig jellegzetesen urbánus jelenségről volt szó, s bár a korábbi mintaévek adatai szerint a vidék eleinte csekély részvételi aránya növekedésnek indult, ennek folyamatát - az 1983-as, a belügyminisztériumi eljárást már a második asszonynév-változtatásnak fenntartó rendelet következtében - nem tudjuk egyértelmüen követni; ugyanakkor feltételezhetjük, hogy az arányok - a házas nök asszonynév-változtatásainak kapcsán látottakéhoz hasonlóan - itt is kiegyensúlyozottabbakká váltak a továbbiakban. A két utolsó mintaévben, a másodszori névváltoztatással élő nők esetében azonban ismét azt állapíthatjuk meg, hogy a falusi lakosság a létszámarányához képest messze hátramaradt a csoporton belül. A falusi lakosságot tehát a névváltoztatások ezen típusában is egyfajta fáziskésés jellemezte a városi, s mindkét csoportot a fövárosi lakosságon belüli előfordulásaihoz képest.

Az életkor szerinti megoszlásnak a korábbi mintaévekben szereplő adatai szerint egyre inkább a fiatalabb korosztályokat érintette ez a folyamat a válások szaporodásával, melyeket követően az elvált nők egyre inkább tudtak és akartak új életet kezdeni. A későbbi, immár másodszori névváltoztatást jelző mintaévekben lett, érthető módon, összességében is jellemzőbb az idősebb korosztályok részvétele; mint fentebb láttuk, a másodszori névváltoztatók - több okból is - jellemzően kevésbé radikális módon, illetve nem egyetlen lépésben tértek vissza leánykori nevük használatához.

8. Befejezésképpen. A magyarországi házassági névviselés kérdésköre a választható névformák széles palettájával nemzetközi viszonylatban is egyedülállóan gazdag és összetett problematikát jelent. E témakört sokféle szempontból, anyagon és módszerrel vizsgálták már, s kutatása további, a jövőben még kiaknázható lehetőségeket rejt magában. Hogy itt csupán egy mindeddig kevéssé vizsgált, bár kifejezetten tanulságos témára utaljak: a nő házasságkötéskor hagyományosan bekövetkező névváltoztatása mellett a férfi immár jó másfél évtizede hasonlóképpen lehetséges névváltoztatásának kérdéskörére és összefüggésrendszerére.

A jelen tanulmány a házassági névviselés különböző formáinak, változási tendenciáinak és különböző kontextusainak kérdéskörét újszerü vonatkozásokkal, illetőleg forrásanyag alapján, egy sajátos jelenségkörére irányulóan vizsgálta; közvetlenül a 20. század második felét átívelően, közvetve s részben azonban a korábbi és későbbi időkre is utaló módon. A férjes asszonyok, illetve az elvált és megözvegyült nők asszonynév-változtatásainak vizsgálata hozzájárulhat a nők modern kori személynévhasználatát befolyásoló tényezők müködésének, változásainak, összefüggéseinek jobb, illetve teljesebb megértéséhez és feltárásához, melynek tanulságai ugyanakkor túl is mutatnak a nyelvészeti, illetve névtani kutatások szükebb értelemben vett hatókörén. 


\section{Hivatkozott irodalom}

AkH. ${ }^{10}=$ A magyar helyesírás szabályai. 10. kiadás. Akadémiai Kiadó, Budapest, 1954.

BarAnyiné Kóczy Judit 2020. Asszonynév, család és identitás összefüggései a XXI. század elején. In: Fóris Ágota - Bölcskei Andrea - Heltai JÁnos Imre szerk., Nyelv, kultúra, identitás. Alkalmazott nyelvészeti kutatások a 21. századi információs térben. IV. Szociolingvisztika, névtan, nyelvtörténet. A MANYE Kongresszusok Előadásai 12/4. Akadémiai Kiadó, Budapest. 39-46. https://doi.org/10.1556/9789634545385

BM = A Belügyminisztérium egykori Állampolgársági Főosztályának irattára.

ERDÉSz Tiborné 1999. A személyiadat és lakcimnyilvántartás összesitett adatai. Népességnyilvántartási Füzetek 6. BM Központi Adatfeldolgozó, Nyilvántartó és Választási Hivatal, Budapest.

FARKAS TAMÁs 2001. A magyar hivatalos család-és asszonynév-változtatások (különös tekintettel a 20. század második felére). Doktori (PhD) értekezés. ELTE BTK, Budapest.

FARKAS TAMÁs 2003. A házassági névviselés új szabályozásához. Magyar Nyelvjárások 41: 133-142.

FARKAs TAMÁs 2009. Családnév-változtatás Magyarországon. A névváltoztatások tényezöi és története a 20. század második felében. Nyelvtudományi Értekezések 159. Akadémiai Kiadó, Budapest.

FÉLIX RITA 1999. Asszonynevek az ezredfordulón. Szakdolgozat. ELTE BTK, Budapest.

FerCSIK ERzSÉBet 2003. Az elvált nők névviseléséről. A XX. század utolsó fél évtizedének statisztikai adatai alapján. In: HaJdú MinÁly - Keszler Borbála szerk., Köszöntö könyv Kiss Jenö 60. születésnapjára. ELTE Magyar Nyelvtudományi és Finnugor Intézet - Magyar Nyelvtudományi Társaság, Budapest. 614-622.

Fercsik ERzséBet 2008. A női nevek kutatása a magyar névtudományban (1958-2007). In: BölCSKEI ANDrea - N. Császi Ildikó szerk., Név és valóság. A VI. Magyar Névtudományi Konferencia elöadásai (Balatonszárszó, 2007. június 22-24.). A Károli Gáspár Református Egyetem Magyar Nyelvtudományi Tanszékének Kiadványai 1. Károli Gáspár Református Egyetem Magyar Nyelvtudományi Tanszéke, Budapest. 342-349.

HaJdú MihÁLy 2000. Müvészasszonyok névhasználata Szentendrén. Névtani Értesítő 22: 45-50.

Megyeri-PÁlffi Zoltán 2013. Név és jog. A névviselés jogi szabályozásának fejlődése Magyarországon. Gondolat Kiadó, Budapest.

PetriK Ferenc szerk. 1988. A családjogi törvény magyarázata 1-2. Közgazdasági és Jogi Könyvkiadó, Budapest.

RAÁtz Judit 2003. A doktori fokozattal rendelkező asszonyok névviselési szokásai. In: HAJdú MIHÁly - Keszler Borbála szerk., Köszöntö könyv Kiss Jenö 60. születésnapjára. ELTE Magyar Nyelvtudományi és Finnugor Intézet - Magyar Nyelvtudományi Társaság, Budapest. 622-628.

RaÁTz JudiT 2004. Új névformákkal az Európai Unióba? Névtani Értesitő 26: 66-73.

RÉVÉSz KaTALIN 2001. Asszonynevek a szentendrei névhasználat tükrében. Névtani Értesitő 23: $57-75$.

Szabó T. AnNAmÁRIa Ulla 2020. A házassági névviselés gyakorlata a 21. századi Magyarországon. Névtani Értesitö 42: 127-141. https://doi.org/10.29178/NevtErt.2020.7

SzAMEL LAJOS 1993. A névviselés és a névváltoztatás, valamint anyakönyvezésük jogi szabályozásának történeti áttekintése. Magyar Közigazgatás 43: 745-751.

Személyi Kálmán 1915. A névjog. Tanulmány a személyiségi jogok köréből. Szerzői kiadás, Budapest. 
SzilÁgyi-Kósa AniKó 2015. Mai személynevek kutatása. In: Farkas TamÁs - Slíz Mariann szerk., Magyar névkutatás a 21. század elején. Magyar Nyelvtudományi Társaság - ELTE Magyar Nyelvtudományi és Finnugor Intézet, Budapest. 145-164.

SzÜTs LÁszLó 1970. Az újabb utónévváltoztatások nyelvészeti tanulságai. In: KÁzMÉr MiKLós - VÉGH JózSEF szerk., Névtudományi elöadások. II. névtudományi konferencia. Budapest, 1969. Nyelvtudományi Értekezések 70. Akadémiai Kiadó, Budapest. 189-192.

UgrócZKY MÁRIA 1997. A névviselésről és a névváltozásról. In: UgrócZKy MÁrIA - Bíró ÁgNes, Új magyar utónévkönyv. BM Kiadó, Budapest. 7-59.

FARKAS TAMÁS

ORCID: https://orcid.org/0000-0002-7732-2302

ELTE Eötvös Loránd Tudományegyetem

Bölcsészettudományi Kar

\section{TAMás FARKAS, Marital name use and marital name changes in the second half of the $20^{\text {th }}$ century}

The study examines changes in the use of marital names and their connections from a novel perspective based on new source material. Its broader subject matter is the changes in the use of official marital names in the second half of the $20^{\text {th }}$ century, which brought about an expansion, and never before seen diversity in the name forms that could be chosen in marriage. (Considering an example of a husband called [examples given in Hungarian name order, with family names first] Hunyadi János and his wife Szilágyi Erzsébet, the wife could at first only be (i) Hunyadi Jánosné using the -né suffix, meaning 'wife of'. From 1953 the wife could choose to be (ii) Hunyadi Jánosné Szilágyi Erzsébet or (iii) Szilágyi Erzsébet. 1974 brought even more choices with (iv) Hunyadiné Szilágyi Erzsébet or (v) Hunyadi Erzsébet. In 2004 the options (vi) Hunyadi-Szilágyi Erzsébet and (vii) Szilágyi-Hunyadi Erzsébet were added. Nevertheless, the study focuses not on the name forms chosen at the time of marriage but later changes that realised movement between the name forms available to women in a given period. The source material of the study is a selected subset of the request documents submitted to the responsible ministry. The study examines the change requests submitted by married women and those submitted by divorced or widowed women separately. The legal background of the phenomenon is explored, alongside the possible motivations for the changes based on written statements and factors that can be deduced from the processes. The proportion of changed and newly chosen name forms, temporal changes in these trends, and the social characteristics of those submitting requests are examined throughout the period that brought significant changes. The paper hopes to contribute to a better understanding of the factors that influence the use, change and connections of names used by women in the Modern Age with this study. 